\title{
ANTIOXIDANT AND PHYTOCHEMICAL QUALITIES OF Solenostemon monostachyus (SoleMon)
}

\author{
Israel Sunmola Afolabi ${ }^{1, 凶}$, Jennifer Olachi Uchendu ${ }^{1,2}$ and Olukayode \\ Samson Mustapha ${ }^{1,3}$ \\ ${ }^{1}$ Department of Biochemistry, College of Science and Technology/Covenant University, Ota, \\ 100122, (Ogun) Nigeria \\ ${ }^{2}$ SustyVibes, Yaba, (Lagos) Nigeria \\ ${ }^{3}$ Promasidor Nigeria limited, Isolo, (Lagos) Nigeria \\ ${ }^{\square}$ Corresponding Author: afolabisunmola@yahoo.com
}

\begin{abstract}
Solenostemon monostachyus (SoleMon) is a lesser-known plant with the potential to serve as a functional food. It is presently assessed for the phytochemical and antioxidant potentials. Appropriate standard spectrophotometric methods were employed to determine the levels of phytochemicals and antioxidant capacities. SoleMon was found to be rich in saponins $(1.150 \pm 0.000 \%)$, tannins $(5.443 \pm 0.065 \mathrm{mg} / \mathrm{g})$, phytate $(13.525 \pm 0.291 \mathrm{mg} / \mathrm{g})$, alkaloids $(7.936 \pm 2.98 \%)$, and oxalate $(0.968 \pm 0.086 \mathrm{mg} / \mathrm{g}$ fresh/wt.). SolMon was also particularly high in bioflavonoids $(6.16 \pm 0.15 \mathrm{mg} / \mathrm{g}) \mathrm{and}$ total polyphenols $(6.03 \pm 0.31 \mathrm{mg} / \mathrm{g})$. SolMon has strong antioxidant-reducing power $(56.06 \pm 1.69 \mu \mathrm{g})$ and $\mathrm{DPPH}$ inhibition level $(53.01 \pm 6.37 \%)$. These phytochemicals and antioxidant properties may account for the health benefits. Keywords: Functional Food, Vegetable, Under-utilized, Medicinal, Phytochemicals, Antioxidants, Health Benefits.

RASĀYAN J. Chem., Vol. 14, No.3, 2021
\end{abstract}

\section{INTRODUCTION}

Vegetables are the fresh part of plants that are safely consumed with minimal or without processing. These parts can be the roots, the stem, the leaves, the seed, or the flowers. Several of these vegetables eliminate or alleviate several chronic diseases like cancer and coronary heart disease. ${ }^{1}$ They also service the body with rich nutrients and numerous phytochemicals that are commonly referred to as "nature's anti-aging wonders".$^{2,3}$ These phytochemicals have antioxidant and anti-carcinogenic properties. They possess the ability to fight against the invasion of potentially harmful free radicals, bacterial, fungal, and viral pathogens. ${ }^{4,5}$ The flavonoids, coumarins, and tannins are serviced by leafy vegetables and are among the other major classes of polyphenolic phytochemicals with immense ability to stabilize the free radicals. ${ }^{6,7}$ These phytochemicals, especially polyphenols, can also reduce the risk of chronic age-related neurological degenerative diseases such as cancer, diabetes, and heart diseases. ${ }^{8,9}$

The nutritional qualities of Solenostermon monostachyus (SolMon) have been described along with those of other edible vegetables. It contains proteins $(40.5 \%)$, carbohydrates $(21.39 \%)$, crude fibre $(12.9 \%)$ and fats $(4.64 \%)$. It is also rich in minerals like calcium, magnesium, iron, zinc, and copper. ${ }^{10}$ The leaves of SolMon are rich in folic acid, and therefore traditionally used to facilitate foetal growth and child delivery. It has also been implicated in reversing sickled blood in patients. Fortunately, it was reportedly consumed as a vegetable in some parts of Africa, indicating that it may be used as a functional food. ${ }^{11}$

Although there are increasing efforts in characterizing the antioxidant and phytochemical properties of some health beneficial plants. Some underutilized plants are yet to be characterized due to their relatively lesser-known status. This study was therefore directed at determining the phytochemicals and the antioxidant properties of the leaves of S. monostachyus that may account for the health benefits of the plants.

\section{Chemicals}

\section{EXPERIMENTAL}

Cathecol, trichloroacetic acid, thiobarbituric acid (TBA), 1,1 diphenyl-2-picryl hydrazyl (DPPH), ferric chloride and acetone were sourced from Sigma Aldrich Incorporation (USA); Folin Ciocalteau reagent, 
ammonium thiocyanate, acetic acid, ammonium hydroxide, and potassium-permanganate were products of Merck Chemicals (Germany); while disodium hydrogen phosphate, ethanol, and n-butanol were products of BDH Lab chemical division (England). All chemicals used were of analytical grade.

\section{Sample Collection}

The leaves of Solenostemon monostachyus (P. Beauv) Brig. (SoleMon; FHI108913) were obtained from the Covenant University environment, Ota, Ogun state. The service of an expert in the Applied Biology Unit of the Biological Sciences Department of Covenant University was engaged to identify the plant. It was after that re-confirmed at the Herbarium unit of Forest Research Institute of Nigeria (FRIN), Ibadan, Nigeria, and deposited there with voucher number FHI108913. The leaves were regularly turned upside down while air-dried at ambient temperature $\left(37.8 \pm 4.7{ }^{\circ} \mathrm{C}\right)$ for two weeks. They were then blended into powder forms and stored in clean airtight containers before their analysis.

\section{Analysis}

The extract obtained from the leaves of SolMon was obtained by following the method of the Singleton, Ruan, Sanford, Haney, Stikeleather. ${ }^{12}$ The extract obtained from the leaves was used for total polyphenol and other antioxidant determinations.

\section{Procedure for Determination of Phytochemical Constituents}

The tannin content was determined by using the method described by Olawole, Olalere, Adeyemi, Okwumabua, Afolabi. ${ }^{13}$ The equivalent tannin concentration of the absorbance values obtained at $725 \mathrm{~nm}$ was thereafter extrapolated from the previously prepared catechol standard graph. The saponin content was carried out as described by Okwu, Josiah. ${ }^{14}$ Alkaloid content was determined as described by Adeniyi, Orjiekwe, Ehiagbonare. ${ }^{15}$ Total oxalate was determined using the method of Agbede ${ }^{16}$, and the phytate content was determined using the method of Reddy, Sathe, Salunkhe. ${ }^{17}$

\section{Procedure for Determination of Antioxidant Profiles}

Total polyphenol was assayed using the method of Afolabi, Ofobrukweta. ${ }^{18}$ The corresponding concentrations of the absorbance values obtained at $700 \mathrm{~nm}$ were extrapolated from a prepared catechol standard graph. The antioxidant-reducing power of the leaf extract was estimated by following a slightly modified method of Yuan, Bone, Carrington. ${ }^{19}$ The antioxidant-reducing power of the extract from the leaves was afterward expressed as ascorbic acid equivalents from a prepared ascorbic acid calibration curve. The antioxidant capacity of the leaves extract was also measured by following the DPPH assay method illustrated by Attoi, Mansouri, Boskou, Kefals. ${ }^{20}$ The absorbance was estimated spectrophotometrically at $517 \mathrm{~nm}$ using methanol as blank, and the resulting antioxidant capacity was expressed as percentage inhibition (\% I) of the DPPH radical, where:

$$
\% \mathrm{I}=[1-(\text { abs of sample/ abs of control })] \times 100 / 1
$$

The thiobarbituric acid value was assayed using the method of Gutteridge. ${ }^{21}$ The absorbances of the supernatant extracts were read at a temperature of at $532 \mathrm{~nm}$ and $25 \pm 2{ }^{\circ} \mathrm{C}$. The level of TBA- reactive compounds were expressed per unit gram using the under-listed formula:

$\mathrm{C}(\mathrm{M})=\mathrm{A} / \mathrm{EL}$. Where $\mathrm{A}=\mathrm{Absorbance} ; \mathrm{C}=$ concentration; $\mathrm{L}=$ path length $=1 \mathrm{~cm}$; and $\mathrm{E}=\mathrm{Molar}$ Extinction coefficient of TBA MDA $=1.5 \times 10^{-5} \mathrm{~m}^{-1} \mathrm{~cm}^{-1}$.

Bioflavonoid content was extracted and assayed using the method described by Helmja, Vaher, Gorbatsova, Kaljurand ${ }^{22}$. The absorbance of the extract obtained was spectrophotometrically determined at $510 \mathrm{~nm}$, and the equivalent concentration was extrapolated from a prepared pyrocatechol standard graph.

\section{Statistical Analysis}

Four replications were used for each determination. The mean values and their standard deviations were derived using the MegaStat version 10.3 computer statistical package. 


\section{RESULTS AND DISCUSSION}

The phytochemical contents and the antioxidant capacity of the leaves of $S$. monostachyus are as indicated in Fig.-1 and Fig.-2, respectively.

\section{Phytochemical Constituents}

The leaves of SolMon possess saponins $(1.150 \pm 0.000 \%)$, phytate $(13.525 \pm 0.291 \mathrm{mg} / \mathrm{g})$, bioflavonoids $(6.16 \pm 0.15 \mathrm{mg} / \mathrm{g})$, and oxalate $(0.968 \pm 0.086 \mathrm{mg} / \mathrm{g}$ fresh/wt.). It also possesses tannins $(5.443 \pm 0.065 \mathrm{mg} / \mathrm{g})$ and alkaloids $(7.936 \pm 2.98 \%)$. A large number of commonly consumed seed legumes provide saponins at a level of $0.02-0.1 \mathrm{mg} / \mathrm{g} .{ }^{23}$ The saponin level $(0.10-10 \mathrm{mg} / \mathrm{g})$ was reported in several major plant sources for medicinal and industrial purposes. ${ }^{24}$

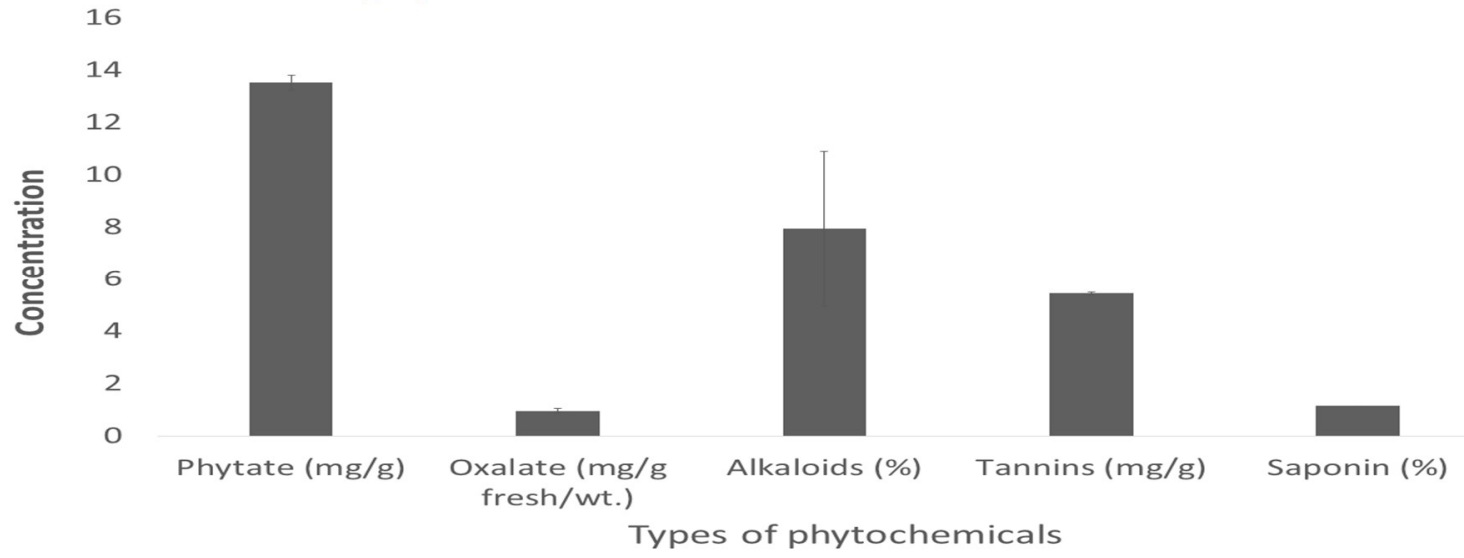

Fig.-1: The levels of phytochemical constituents in the leaves of Solenostermon monostachys.

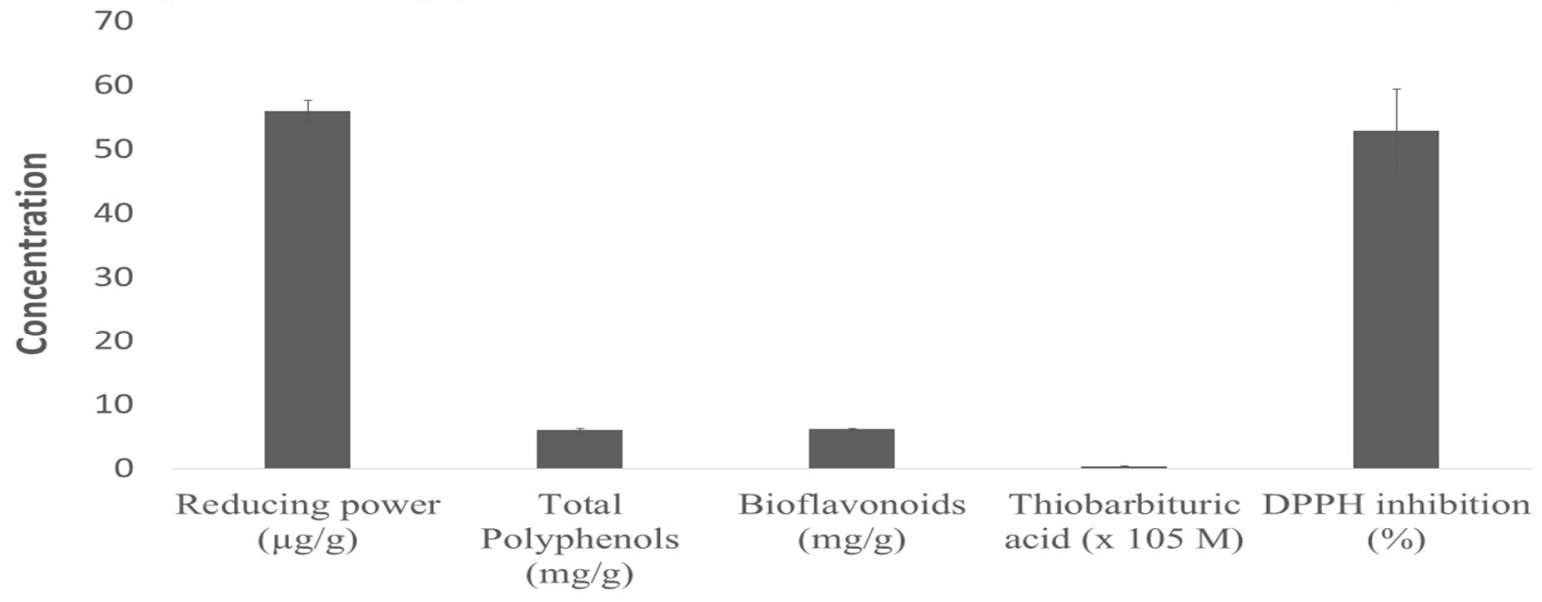

Antioxidant profiles

Fig.-2: The antioxidant potentials in the leaves of Solenostermon monostachys

Saponins were reported to be safely consumed by human vegetarians within the range of $100-200 \mathrm{mg} / \mathrm{day}$. ${ }^{25}$ It was successfully administered to rats for 21 days at a level of $0.02-0.1 \mathrm{mg} / \mathrm{g}$ with a practicable reduction in appetite for food, and the levels of high glucose sugar, LDL-cholesterol, total cholesterol, and triglycerides. HDL-cholesterol was, however, increased by the same dosage administration. ${ }^{26}$

SolMon has a high level of saponins $(1.150 \pm 0.000 \%)$, phytate $(13.525 \pm 0.291 \mathrm{mg} / \mathrm{g})$, and bioflavonoids $(6.16 \pm 0.15 \mathrm{mg} / \mathrm{g})$. SolMon was low in oxalate levels $(0.968 \pm 0.086 \mathrm{mg} / \mathrm{g}$ fresh/wt.). It also possesses tannins $(5.443 \pm 0.065 \mathrm{mg} / \mathrm{g})$ and alkaloids $(7.936 \pm 2.98 \%)$. SolMon was also particularly high in total polyphenols $(6.03 \pm 0.31 \mathrm{mg} / \mathrm{g})$ and was found to have strong antioxidant-reducing power $(56.06 \pm 1.69 \mu \mathrm{g})$ and DPPH inhibition level $(53.01 \pm 6.37 \%)$. The phytochemical analysis revealed bioactive substances like tannins, oxalate, saponins, alkaloids, and phytate (Fig.-1). These may account for the health benefits of SolMon. ${ }^{27}$ SolMon may, therefore, have the potential of being used for health benefits purposes due to their phytate 
level (Fig.-1). The phytate possesses antioxidant activity. ${ }^{28}$ Also, the antibacterial properties and antioxidant activities of tannins have been documented. ${ }^{27}$ Tannins are harmful when consumed in excessive amounts. ${ }^{29}$ The high tannin levels in the leaves also indicate that the consumption of the plants at a high level should be discouraged, except they are subjected to further appropriate processing methods like cooking. Processing methods such as fermentation and/or boiling are often employed to reduce the intolerable high levels of these phytochemicals in the seeds of sorghum and Adenanthera parvonina to be safe for consumption. ${ }^{13,30-32}$ The benefits of alkaloids, saponins, and tannins in making the various antibiotics commonly used in treating myriad strains of pathogens had earlier been reported. ${ }^{33}$ Therefore, the leaves of SolMon may also be used to treat diseases induced by pathogenic organisms. There is also the possibility of extracting the bioactive in the plants for drug production. An account of some therapeutic bioactive that is present in the leaves of the SolMon had been illustrated. ${ }^{34}$

\section{Antioxidant Properties}

SolMon was also particularly endowed total polyphenols $(6.03 \pm 0.31 \mathrm{mg} / \mathrm{g})$ and was found to have antioxidant-reducing power $(56.06 \pm 1.69 \mu \mathrm{g} / \mathrm{g})$ and DPPH inhibition level of 53.01 $\pm 6.37 \%$ (Fig.-2). Antioxidant molecules are essential to support the natural body antioxidants in eliminating the harmful effects of free radicals in consumers. ${ }^{35,36}$ The release of free radicals is a crucial process that takes place even in the normal body metabolism of humans, during which myriad free radicals are generated as a byproduct. ${ }^{37}$ It is normal for all these free radicals to be neutralized in the body by engaging the service of the enzymatic and the non-enzymatic antioxidants. These biochemical actions are also enhanced by engaging the dietary antioxidants supplemented in daily diets containing fruits and vegetables. ${ }^{37}$

\section{Reducing Power}

The reducing power of a compound gives a reflection of its antioxidant potential. ${ }^{38}$ Estimation of the reducing antioxidant power capitalizes on the ability of the components in the extracts to convert the oxidized form of iron $\left(\mathrm{Fe}^{2+}\right)$ that is present in ferric chloride to the ferrous $\left(\mathrm{Fe}^{3+}\right)$ state. ${ }^{39}$ SolMon demonstrated a very high reducing power $(56.06 \pm 1.69 \mu \mathrm{g} / \mathrm{g})$, a characteristic similar to that of medicinal plants. The reducing power was more than the low antioxidant-reducing power that was earlier reported for edible plants. ${ }^{40,41}$

\section{Total Polyphenol Content}

SolMon also possesses similar polyphenol levels $(6.03 \pm 0.31 \mathrm{mg})$ to those of the earlier reported functional foods. ${ }^{13,42}$

\section{Bioflavonoids}

Bioflavonoids are the secondary metabolites that exhibit antioxidant activities, including free radical scavenging effects, the capacity to transfer electrons, and chelating abilities. ${ }^{43,44}$ The green leafy vegetables, soft fruits, and medicinal plants were reported to exhibit higher levels of flavonoids. ${ }^{45,46}$ SolMon possessed high bioflavonoid contents $(6.16 \mathrm{mg} / \mathrm{g})$ at a level higher than the currently known medicinal foods. ${ }^{13,42}$

\section{DPPH Radical Scavenging Activity}

DPPH is a stable nitrogen-centered free radical, which is insensitive to side reactions such as metal chelation and enzyme inhibition. ${ }^{47}$ The DPPH level $(53.01 \%)$ for SolMon was higher than the concentration (6-16 \%) reported for sorghum. ${ }^{13}$

\section{Thiobarbituric Acid Value}

The thiobarbituric acid levels of the extract from the leaves of SolMon displayed a certain degree of lipid peroxidation. The peroxidation is attributed to the ability of the chemical constituents to interacts with DPPH radicals (Table-1). Thiobarbituric acid value is a reflection of the rate of oxidative rancidity. High lipid peroxidation is an indication of low antioxidant status. ${ }^{44,48}$ Thiobarbituric acid values in the leaves of SolMon were generally low, indicating the inhibition of lipid peroxidation reactions due to the presence of strong antioxidants in the plants. The strong antioxidant composition confirms the usefulness of SolMon 
for medicinal purposes. The antioxidant activities of the extract from the leaves of SolMon as its affects albino rats were accounted for. ${ }^{49}$ This present finding corroborates the earlier findings of Osikoya, Afolabi, Okafor, Rotimi ${ }^{49}$, where a dosage of $150-200 \mathrm{mg} / \mathrm{Kg}$ of the extract from SolMon was found to be appropriate to maximize the antioxidant potential of the plant in managing oxidative stress-induced diseases. This carefully recommended dosage is essential since the antioxidant activities of molecules are often converted to pro-oxidant at excessively higher concentrations. ${ }^{50,51}$

\section{CONCLUSION}

The leaves of $S$. monostachyus possessed high antioxidant capacity. It may, therefore, be useful in preventing oxidative stress generated by excessive free radicals and degenerative diseases. This leaf showed more tendencies to being used as medicinal plants than being used for nutritional purposes. Consequently, appropriate processing methods are essential before consuming the leaves the $S$. monostachyus as vegetables.

\section{ACKNOWLEDGEMENT}

The management of Covenant University, Ota, Nigeria, is appreciated the financial support toward the payment of the processing fee for this article. The technical support from Mr. Alaba O. Adeyemi during the experimentation is also highly appreciated.

\section{REFERENCES}

1. F. Muanda, D. Koné, A. Dicko, R. Soulimani, and C. Younos, Evidence-Based Complementary and Alternative Medicine, 2011 (2011), https://doi.org/10.1093/ecam/nep109

2. S. Gupta, and J. Prakash, Plant Foods for Human Nutrition, 64(1), 39(2009), https://doi.org/10.1007/s11130-008-0096-6

3. M. Edelman, and M. Colt, Frontiers in Chemistry, 4, 32 (2016), https://doi.org/10.3389/fchem.2016.00032

4. N. Gruda, Critical Reviews in Plant Sciences, 24(3), 227(2005), https://doi.org/10.1080/07352680591008628

5. K. A. Steinmetz, and J. D. Potter, Journal of the American Dietetic Association, 96(10), 1027(1996), https://doi.org/10.1016/S0002-8223(96)00273-8

6. Y. Pan, K. Wang, S. Huang, H. Wang, X. Mu, C. He, J. X., J. Zhang, and F. Huang, Food Chemistry, 106(3), 1264(2008), https://doi.org/10.1016/j.foodchem.2007.07.033

7. F. N. Iheagwam, E. N. Israel, K. O. Kayode, O. C. De Campos, O. O. Ogunlana, and S. N. Chinedu, Evidence-Based Complementary and Alternative Medicine, 2019, 1 (2019), https://doi.org/10.1155/2019/6316231

8. F. Joulia, J. G. Steinberg, F. Wolff, O. Gavarry, and Y. Jammes, Respiratory Physiology \& Neurobiology, 133(1-2), 121(2002), https://doi.org/10.1016/S1569-9048(02)00133-7

9. W. J. Craig, American Journal of Clinical Nutrition, 89(5), 1627S(2009), https://doi.org/10.3945/ajen.2009.26736N

10. I. S. Afolabi, O. N. Akpokene, D. V. Fashola, and T. C. Famakin, Journal of Natural Product and Plants Resource, 2(2), 261(2012).

11. I. S. Afolabi, I. O. Osikoya, O. D. Fajimi, P. I. Usoro, D. O. Ogunleye, T. Bisi-Adeniyi, A. O.Adeyemi, and B. T. Adekeye, BMC Complementary and Alternative Medicine, 12, 262(2012), https://doi.org/10.1186/1472-6882-12-262

12. J. A. Singleton, M. Ruan, J. H. Sanford, C. A. Haney, and L. F. Stikeleather, Journal of the American Oil Chemists' Society, 76(1), 49(1999), https://doi.org/10.1007/s11746-999-0046-y

13. T. D. Olawole, A. T. Olalere, O. A. Adeyemi, O. Okwumabua, and I. S. Afolabi, Rasāyan Journal of Chemistry, 12(2), 523(2019), https://doi.org/10.31788/RJC.2019.1224066

14. D. E. Okwu, and C. Josiah, African Journal of Biotechnology, 5(4), 357(2006).

15. S. A. Adeniyi, C. L. Orjiekwe, and J. E. Ehiagbonare, African Journal of Biotechnology, 8(1), 110(2009).

16. J. O. Agbede, Pakistan Journal of Nutrition, 3(4), 222(2004), https://doi.org/10.3923/pjn.2004.222.227

17. N. R. Reddy, S. K. Sathe, and D. K. Salunkhe, Advances in Food Research, 28, 1 (1982), https://doi.org/10.1016/S0065-2628(08)60110-X 
RASĀYAN J. Chem.

Vol. 14 | No. 3 |2154-2160| July - September | 2021

18. I. S. Afolabi, and K. Ofobrukweta, Journal of Medicinal Plants Research, 5(14), 3115 (2011).

19. Y. V. Yuan, D. E. Bone, and M. F. Carrington, Food Chemistry, 91(3), 485(2005), https://doi.org/10.1016/j.foodchem.2004.04.039

20. A. Attoi, A. Mansouri, G. Boskou, and P. Kefals, Food Chemistry, 89(1), 27 (2005).

21. J. M. C. Gutteridge, Analytical Biochemistry, 69(2), 518(1975), https://doi.org/10.1016/00032697(75)90155-4

22. K. Helmja, M. Vaher, J. Gorbatsova, and M. Kaljurand, Proceedings of the Estonian Academy of Sciences. Chemistry, 56(4), 172 (2007).

23. B. Caballero, The Encyclopedia of Food Sciences and Nutrition, 2 ed., 5095, USA: Academic Press (2003).

24. D. Kregiel, J. Berlowska, I. Witonska, H. Antolak, C. Proestos, M. Babic, L. Babic, and B. Zhang, Application and Characterization of Surfactants, R. Najjar, ed., pp. 183, London (UK): IntechOpen (2017), https://doi.org/10.5772/68062

25. K. Bone, and S. Mills, Modern Herbal Medicine, K. Bone and S. Mills, eds., pp. 17, USA: Churchill Livingstone (2013), https://doi.org/10.1016/b978-0-443-06992-5.00002-5

26. M. Marrelli, F. Conforti, F. Araniti, and G. A. Statti, Molecules, 21(10), 1404(2016), https://doi.org/10.3390/molecules21101404

27. M. I. Gil, F. A. Tomás-Barberán, B. Hess-Pierce, D. M. Holcroft, and A. A. Kader, Journal of Agricultural and Food Chemistry, 48(10), 4581(2000), https://doi.org/10.1021000404a

28. C. M. M. Coelho, C. M. Bellato, A. K. M. Garcia, V. A. Vitorello, and R. A. Azevedo, Brazilian Archives of Biology and Technology, 51(1), 163(2008), https://doi.org/10.1590/S151689132008000100020

29. P. Ojha, R. Adhikari, R. Karki, A. Mishra, U. Subedi, and T. B. Karki, Food Science \& Nutrition, 6(1), 47 (2018), https://doi.org/10.1002/fsn3.525

30. I. S. Afolabi, G. D. Marcus, T. O. Olanrewaju, and V. Chizea, Journal of Natural Products, 4, 17 (2011).

31. I. S. Afolabi, I. C. Nwachukwu, C. S. Ezeoke, R. C. Woke, O. A. Adegbite, T. D. Olawole, and O. C. Martins, Frontiers in Nutrition, 5, 9(2018), https://doi.org/10.3389/fnut.2018.00009

32. I. Fidrianny, A. Rahmawati, and R. Hartati, Rasāyan Journal of Chemistry, 11(4), 1628(2018), https://doi.org/10.31788/rjc.2018.1143091

33. D. Kubmarawa, A. G. A., N. M. Enwerem, and D. A. Okorie, African Journal of Biotechnology, 6(14), 1690 (2007).

34. I. S. Afolabi, A. F. Jolaoluwa, V. O. Awogbindin, and P. T. Amosun, Planta Medica, 81(S01), S1 (2016), https://doi.org/10.1055/s-0036-1596424

35. G. A. Otunola, O. B. Oloyede, A. T. Oladiji, and A. J. Afolayan, Biological Research, 47, 5 (2014), https://doi.org/10.1186/0717-6287-47-5

36. S. Awad, M. I. El-Sayed, A. Wahba, A. El Attar, M. I. Yousef, and M. Zedan, Journal of Dairy Science, 99(11), 8499(2016), https://doi.org/10.3168/jds.2015-10626

37. I. C. Jang, J. H. Park, E. Park, H. R. Park, and S. C. Lee, Plant Foods for Human Nutrition, 63(4), 205 (2008), https://doi.org/10.1007/s11130-008-0086-8

38. S. Meir, J. Kenner, B. Akiri, and S. Philosoph-Hadas, Journal of Agricultural and Food Chemistry, 43(7), 1813(1995), https://doi.org/10.1021/jf00055a012

39. M. R. Moein, S. Moein, and S. Ahmadizadeh, Molecules, 13(11), 2804(2008), https://doi.org/10.3390/molecules13112804

40. C. Y. Lin, L. C. Lin, S. T. Ho, Y. T. Tung, Y. H. Tseng, and J. H. Wu, Evidence-Based Complementary and Alternative Medicine, 2014, 283938(2014), https://doi.org/10.1155/2014/283938

41. F. L. Hakkim, G. Arivazhagan, and R. Boopathy, Journal of Medicinal Plants Research, 2(9), 250(2008).

42. M. J. Rahman, A. C. de Camargo, and F. Shahidi, Journal of Functional Foods, 35(August), 622 (2017), https://doi.org/10.1016/j.jff.2017.06.044

43. M. Amzad Hossain, S. M. Salehuddin, M. J. Kabir, S. M. M. Rahman, and H. P. V. Rupasinghe, Food Chemistry, 113(1), 185(2009), https://doi.org/10.1016/j.foodchem.2008.07.085 


\section{RASĀYAN J. Chem.}

Vol. 14 | No. 3 |2154-2160| July - September | 2021

44. S. M. Sinaga, S. Sudarmi, I. Iksen, K. Kevin, and M. P. Sari, Rasāyan Journal of Chemistry, 11(4), 1604(2018), https://doi.org/10.31788/rjc.2018.1144067

45. M. R. Saha, S. M. R. Hasan, R. Akter, M. M. Hossain, M. S. Alam, and M. E. H. Mazumder, Bangladesh Journal of Veterinary Medicine, 6(2), 197(2008), https://doi.org/10.3329/bjvm.v6i2.2336

46. F. N. Iheagwam, O. O. Ogunlana, O. E. Ogunlana, I. Isewon, and J. Oyelade, Bioinformatics and Biology Insights, 13, 1 (2019), https://doi.org/10.1177/1177932218821371

47. A. Dabija, G. G. Codină, S. Ropciuc, A.-M. Gâtlan, and L. Rusu, Journal of Food Quality, 2018(1), 5329386 (2018), https://doi.org/10.1155/2018/5329386

48. N. Dasgupta, and B. De, Food Chemistry, 101(2), 471(2007), https://doi.org/10.1016/j.foodchem.2006.02.003

49. I. O. Osikoya, I. S. Afolabi, A. M.-J. Okafor, and S. O. Rotimi, International Journal of Biochemistry Research \& Review, 18(4), 1(2017), https://doi.org/10.9734/ijbcrr/2017/35719

50. L. Cui, and E. A. Decker, Journal of the Science of Food and Agriculture, 96(1), 18(2016), https://doi.org/10.1002/jsfa. 7320

51. J. Du, J. J. Cullen, and G. R. Buettner, Biochimica et Biophysica Acta, 1826(2), 443(2012), https://doi.org/10.1016/j.bbcan.2012.06.003

[RJC-5587/2020] 